\title{
Effects of soil and water conservation practices on soil physicochemical properties in Gumara watershed, Upper Blue Nile Basin, Ethiopia
}

\author{
Mengie Belayneh ${ }^{1 *}$ D, Teshome Yirgu ${ }^{2}$ and Dereje Tsegaye ${ }^{3}$
}

\begin{abstract}
Background: Soil erosion is among the foremost causes of declining soil resources in Ethiopia, which in turn affect agricultural productivity. To limit this problem, for the last two decades in Gumara watershed, soil and water conservation measures have been practiced through free labor community mass-mobilization. However, their effect on soil fertility has not been evaluated. This study investigated the impact of implemented soil and water conservation measures on fertility improvement in the Gumara watershed. Both composite and core soil samples were taken from upstream, midstream, and downstream adjacent conserved and non-conserved cultivated and grazing plots. Selected soil fertility indicators were analyzed using standard laboratory procedures.

Results: Soil and water conservation practices have resulted in a statistically significantly higher mean values of total nitrogen, exchangeable $\mathrm{Na}^{+}$and $\mathrm{Mg}^{2+}$ at $p<0.01$, and of soil organic carbon and organic matter at $p<0.05$ in the watershed. The clay content, soil reaction, cation exchange capacity, and exchangeable $\mathrm{K}^{+}$showed nonsignificant, but higher mean values in conserved plots. Furthermore, the effects of conservation practices on soil properties were found more effective in cultivated land uses as compared to that of grazing land uses. This is because conservation treatments had significant effects on organic carbon, total nitrogen, exchangeable $\mathrm{Na}^{+}$and $\mathrm{Mg}^{2+}$ in cultivated land uses but only on exchangeable $\mathrm{Na}^{+}$in grazing land uses. The interaction effect of treatments and land uses did not reach a statistically significant result for any of the soil properties considered in this study.
\end{abstract}

Conclusion: Conservation measures have important implications for improving soil fertility in the Gumara watershed. Therefore, proper guidance and follow-up, use of agro-forestry and grass strips, and maintenance are required for the watershed's sustainability and good soil conditions.

Keywords: Soil properties, Soil erosion, Soil and water conservation, Analysis of variance, Gumara watershed

\section{Introduction}

Land degradation and its related decline in the productivity potential of agricultural land are challenging the economic and social well-being of the current and future generations on earth (Keno and Suryabhagavan 2014; Haregeweyn et al. 2012). Soil erosion is the main cause of land degradation and a leading factor contributing to poor

\footnotetext{
* Correspondence: mengie1980@yahoo.com

'Department of Geography and Environmental Studies, Mettu University, Box 318, Mettu, Ethiopia

Full list of author information is available at the end of the article
}

agricultural development in developing countries (Gemechu 2016). Currently, soil resources are the main sources of livelihoods for most people of the world, such human exploitation being the foremost factor for soil degradation (Molla and Sisheber 2017). In developing countries, many people have been settled in the highlands due to favorable agricultural and ecological conditions, leading to high population densities and causing resource degradation (Haregeweyn et al. 2017; Nyssen et al. 2008).

Cultivation of marginal lands, forest degradation for farming, and overgrazing are the major causes of 
increasing vulnerability of agricultural land to soil erosion in Ethiopia (Adimassu et al. 2014). The slope steepness, long cultivation history with outdated technology, and overgrazing make soil erosion more severe in Ethiopia (Nyssen et al. 2004). It has been identified as a major threat to the national economy (Hurni 1993) and among the main challenges influencing the sustainability of agriculture (Molla and Sisheber 2017). As a result, two-thirds of the population of Ethiopia has been affected by soil erosion mainly associated with the conversion of forest to agricultural land (Hurni et al. 2015). This is indicated by a $0.4 \%$ increase in crop yields and a $5.7 \%$ increase in cultivated land from 1991 to 2003 (International Monetary Fund 2005). The net soil loss increased from 130 to 182 million metric tons from 1995 to 2005 (Environment for Development 2010).

As part of the Ethiopian highlands, the Upper Blue Nile Basin experiences high soil erosion rate (0200 tons $\mathrm{ha}^{-1}$ year $^{-1}$ ) (Haregeweyn et al. 2017) and 131 million tons of soil loss annually because of poor land use management systems (Betrie et al. 2011). The Gumara watershed is part of this basin that is affected by high soil erosion (Belayneh et al. 2019; Hurni et al. 2005) and among the highest mean runoff portion in the basin (Haregeweyn et al. 2016).

To solve this problem, soil and water conservation (SWC) practices were initiated in Ethiopia during the 1970s and 1980s (Adgo et al. 2013; Adimassu et al. 2014; Haregeweyn et al. 2015; Nyssen et al. 2008). The main intent of the initiatives was to minimize erosion, restore soil fertility, rehabilitate degraded land, and increase agricultural productivity (Mekuria et al. 2007). Conservation programs were reviewed in different phases by considering their success (Haregeweyn et al. 2012). Since the 1990s, the implementation of SWC measures has been an integral part of agricultural extension packages (Bewket and Sterk 2002). Community-based watershed management approaches and a nationwide 30-day public campaign (community mass-mobilisation) for watershed management have been implemented since 2009 (Haregeweyn et al. 2012).

However, programs were targeted on areas frequently affected by drought in the northern and northeastern parts of the country aiming at social protection but not so much at resource conservation (Haregeweyn et al. 2015; Mekuriaw et al. 2018). Active erosion and high annual runoff rates occur in the northwestern highlands of the country (Haregeweyn et al. 2017; Nyssen et al. 2004), which are characterized by high and erosive rainfall and poor land management (Nyssen et al. 2004).

The effectiveness of SWC measures was evaluated by several studies but most of them focused on the semiarid northern part of the country (Haregeweyn et al.
2016; Nyssen et al. 2010). Few studies were conducted in the northwestern highlands (Haregeweyn et al. 2015). The efficiency and effectiveness of SWC measures is subject to both the prevailing agro-ecology and the type of conservation measures implemented (Haregeweyn et al. 2015). This indicates the need for local and agro-ecologically based evaluation of the impacts of SWC measures in high potential northwestern highlands.

On the other hand, there is no consent on the effectiveness of SWC interventions among the research findings reported so far (Dagnew et al. 2015). Some argue that SWC contributes for reduction in runoff and sediment loss (Mekuriaw 2017) and increased soil moisture conservation (Haregeweyn et al. 2015; Nyssen et al. 2010). On the other side, it is reported that SWC structures were not effective in reducing soil erosion (Bewket and Sterk 2002) and had not resulted in decreasing sediment concentrations (Temesgen et al. 2012). This indicates that there is a gap in the evaluation of the impacts of SWC interventions.

In the Gumara watershed like most northwestern highlands, different SWC structures were implemented by farmers through community mass-mobilization since 1995. However, soil erosion is still very high and a threatening problem for soil resource and agriculture (Belayneh et al. 2019). In the sub-humid northwestern highlands, little attention has been given to SWC interventions and little information is documented on effectiveness of SWC measures (Haregeweyn et al. 2015). Insufficient data on the effectiveness of SWC practices could lead to ineffective planning, progress, and realization of SWC initiatives.

Hence, evaluating the impacts of SWC practices has been vital to learn lessons from its success and limitations of the initiative. In this regard, the objectives of the study were (1) to investigate the impact of implemented SWC measures on soil physicochemical properties in the watershed, and (2) to evaluate the effectivness of SWC in improving soil fertility under different land uses (cultivated and grazing land) in sub-humid Gumara watershed.

\section{Materials and methods \\ The study area}

Gumara watershed (Fig. 1) is located in Dega Damot district, ${ }^{1}$ West Gojjam Zone, Northwestern Ethiopia. It is among the headquarter streams of Blue Nile River (Abay river). It extends from $10^{\circ} 50^{\prime} 15^{\prime \prime}$ to $11^{\circ}$ $0^{\prime} 40^{\prime \prime} \mathrm{N}$ and $37^{\circ} 30^{\prime} 40^{\prime \prime}$ to $37^{\circ} 41^{\prime} 22^{\prime \prime} \mathrm{E}$. The watershed covers a total area of 20,438 ha.

\footnotetext{
${ }^{1}$ District: locally referred and roughly equivalent to "woreda," is the next lower level of administration in the current Ethiopian administration system.
} 


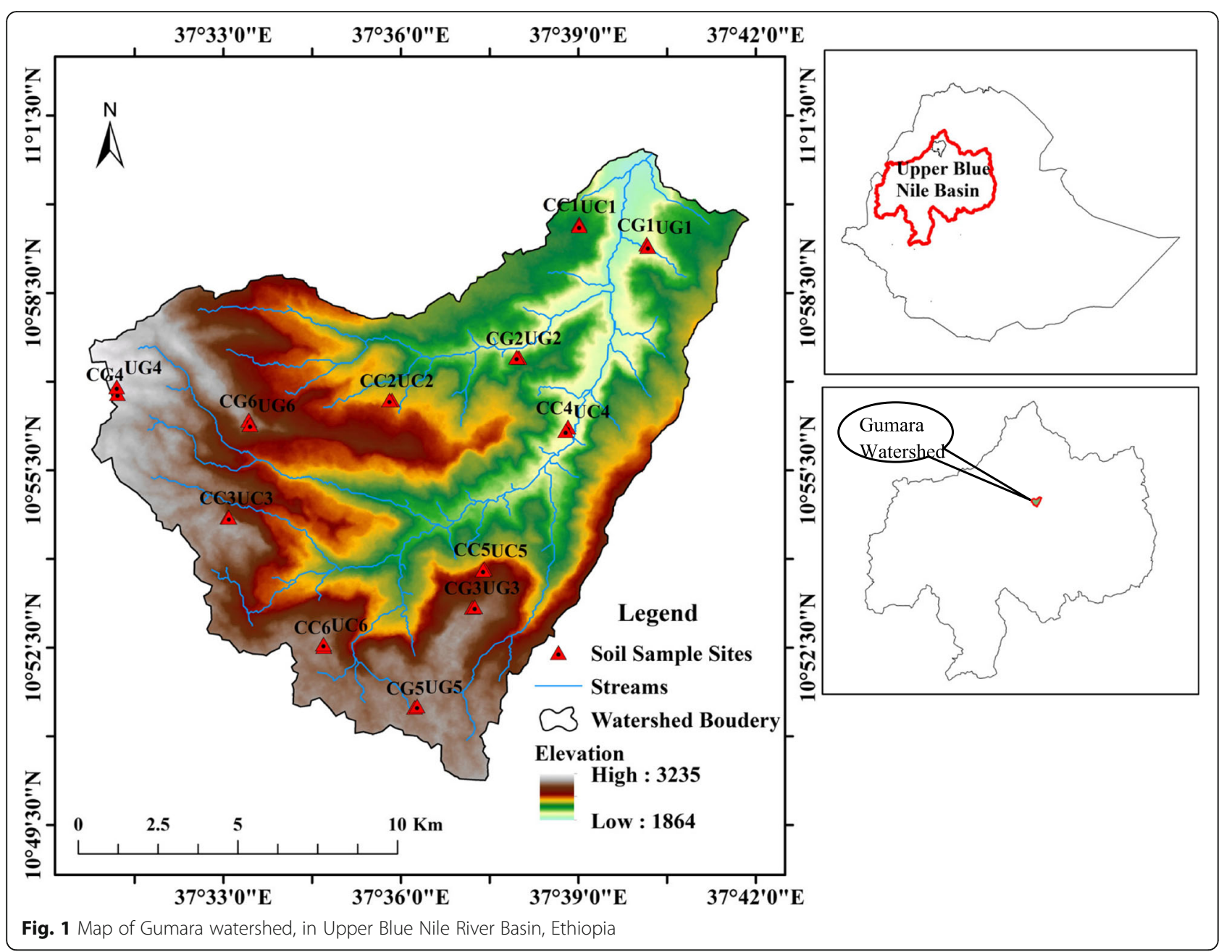

Gumara watershed is part of the northern highland, dominated by the Oligo-Miocene volcanic trap basalt rock underlain by the early Tertiary volcanoes (Abbate et al. 2015). The watershed is characterized by diverse topographic conditions and its elevation ranges from 1864 to $3235 \mathrm{~m}$ above sea level.

According to the soil map of the watershed collected from Ministry of Water, Irrigation, and Energy, the soil of the watershed is characterized by haplic luvisols, haplic nitisols, and haplic alisoils (Ministry of Water Resources of Ethiopia (MoWR) 1998). Haplic alisols is the dominant soil type in the watershed, covering an area of $90.67 \mathrm{~km}^{2}$ followed by Haplic luvisols $\left(70.8 \mathrm{~km}^{2}\right)$. The watershed is characterized by high amount of rainfall, which received $2078.1 \mathrm{~mm}$ in a unimodal rainfall pattern (computed from 20 years national meteorology agency data of Feres Bet rainfall station). It experienced $16.6{ }^{\circ} \mathrm{C}$ mean annual temperature (Fig. 2). The watershed has Dega (tropical) and Woina Dega (sub-tropical) agroecologies, in which $71 \%$ of the watershed has highland tropical climate.
Cultivated land, forest land, grazing land, shrub/wood land, bare land, and built-up areas are the major land uses/covers in the watershed (Belayneh et al. 2019). Of which the cultivated land covers 58.09\%. Subsistence agriculture, in the form of mixed crop and livestock system, is the main source of livelihood, accounting for $90 \%$ of the households in the watershed.

The total population of the District for the years 1994, 2007, and 2017 were 130,939, 152,343, and 179,078 respectively (Central Statistical Agency of Ethiopia (CSA) 1994, 2007) and 2017 (Dega Damot District Administration office 2017), with an increase of $16.35 \%$ in 13 years (1994-2007) and $17.16 \%$ in 10 years (2007-2017).

\section{Methods of data collection}

The impacts of SWC measures were evaluated using adjacent conserved and non-conserved plots in the Gumara watershed. Sites having conserved and nonconserved plots adjacently were identified through reconnaissance survey and Google Earth image. For several reasons, some plots had not been conserved 


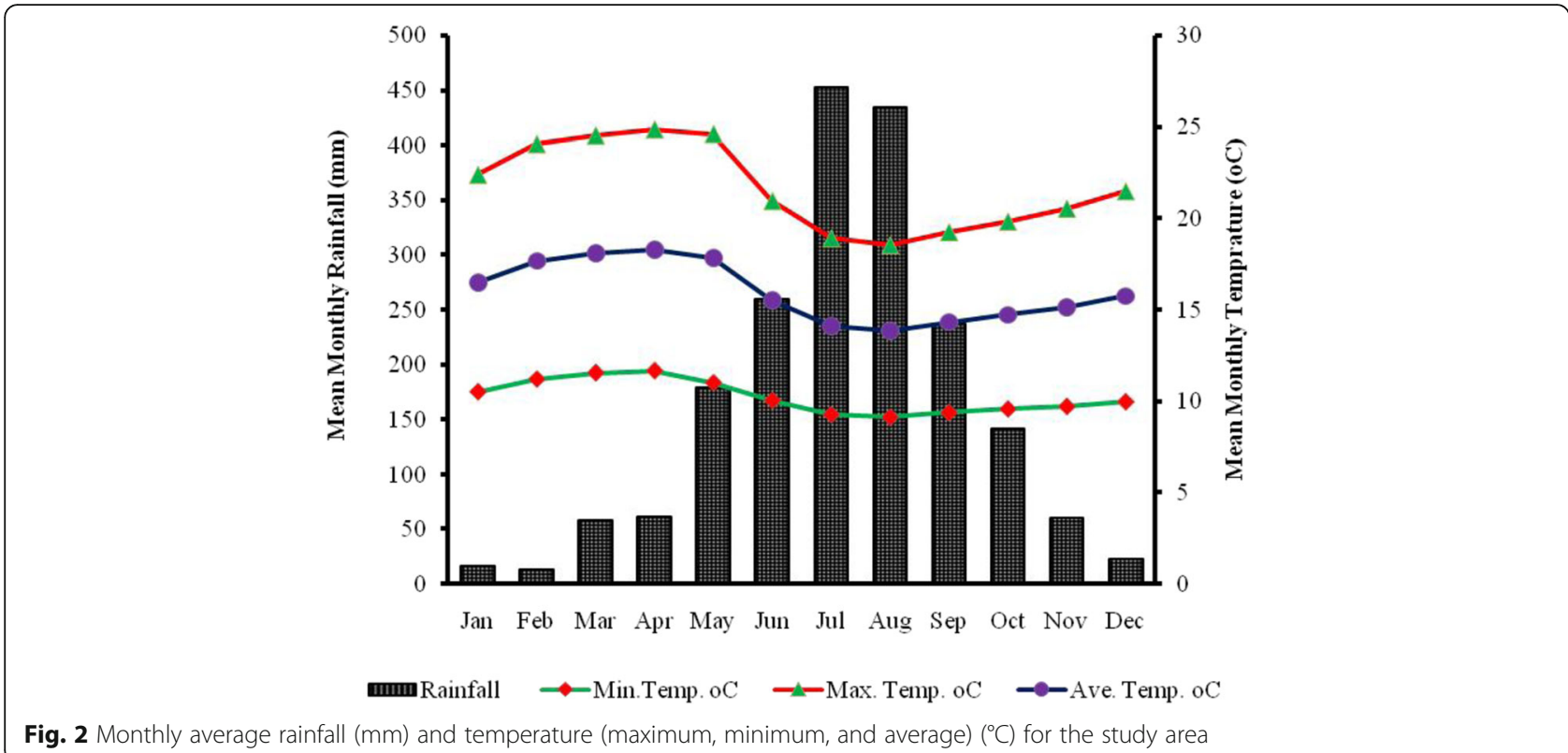

Fig. 2 Monthly average rainfall $(\mathrm{mm})$ and temperature (maximum, minimum, and average) $\left({ }^{\circ} \mathrm{C}\right)$ for the study area

adjacent to the conserved plots in different portions of the watershed. This was vital to make sample sites relatively similar in physical and environmental conditions for comparison and the variation could be due to SWC structures. Soil samples were collected using 15-cm depth auger and $294.375 \mathrm{~cm}^{3}$ core sampler at a depth of $0-30 \mathrm{~cm}$. A total of 24 composite and core soil samples (two treatments [conserved and non-conserved plots] " two land uses * six replicates) were collected. Soil samples were collected from upstream, midstream, and downstream part of the watershed to make representative for the whole watershed. Soil samples from upper $(0.5 \mathrm{~m}$ from the upper bund), middle (midpoint between two successive bunds), and lower ( $0.5 \mathrm{~m}$ from the lower bund) part of two successive bunds were composited for conserved soil samples to make it more representative, because upper, middle, and lower portion of the area between terraces may have different soil fertility. One kilogram composite soil was packed from each soil sampling site for laboratory analysis. Purposive sampling was applied to select adjacent conserved and non-conserved plots and to represent large area. Core samples were taken along with each composite sample. Samples from cultivated land were taken after crop harvest with similar crop land uses.

Direct field observation and key-informant interviews were conducted to support the laboratory result about the effectiveness of SWC practices. Direct field observation was conducted to see the current physical conditions of conservation structures, destructions, and maintenance. Key-informant interview was done with experienced natural resources management unit authorities (five), developmental agents (three) and kebele ${ }^{2}$ agricultural professionals (three), and 27 selected farmers (nine from each sample kebele) to collect supporting data about the effectiveness of conservation measures in the watershed. Sample farmers were selected from the three sample kebeles (among eight watershed kebeles) using simple random sampling. Sample households were selected through purposive sampling method by considering farmers understanding, participation in campaign work, and their involvement in different decision-making processes in the kebeles. The sex and age of farmers and their adoption level of SWC measures were also considered in the selection process.

\section{Laboratory analysis}

Composite soil samples were air-dried, grinded, and sieved to pass through a $2 \mathrm{~mm}$ sieve to make it ready for lab analysis. The soil laboratory analysis was done at Amhara National Regiional State Agriculture Office, Debre Markos soil research and fertility iprovment center. Selected soil fertility indicators such as soil texture, soil $\mathrm{pH}$, bulk density, total nitrogen, organic carbon, available phosphorus, exchangeable bases, and caution exchange capacity were analyzed using standard laboratory procedures. For the analysis of total nitrogen and organic carbon content, the soil sample was further sieved by $0.5 \mathrm{~mm}$ sieve.

${ }^{2}$ Kebele: Is the lowest level of administration in the current Ethiopian government administration system. 
The soil bulk density was determined by core sampler method described in Black et al. (1965). The determination of soil particle size proportions were carried out by hydrometer method suggested by Sakar and Haldar (2005). Following this, the determination of soil texture and textural classification ware identified using equilateral triangle suggested by United States Department of Agriculture (USDA) and described by Osman (2013). Soil reaction (soil $\mathrm{pH}$ ) was determined by a 1:2.5 soil: water ratio using a $\mathrm{pH}$ meter as described by Van Reeuwijk (2002). The soil organic carbon (SOC) concentration was determined by using Walkley and Black rapid titration method as described in Sakar and Haldar (2005). Soil organic matter (SOM) was determined by multiplying percent organic carbon by 1.724 (Jones 2001). Total nitrogen (TN) was determined by the modified Kjeldahl methods as modified by Sakar and Haldar (2005). The available phosphorus (av. P) content was determined using Olsen extraction method as described by Van Reeuwijk (2002). The exchangeable bases and CEC were determined by using ammonium acetate method (Sakar and Haldar 2005). $\mathrm{Ca}_{2}{ }^{+}$and $\mathrm{Mg}_{2}{ }^{+}$were determined by atomic absorption spectrophotometer; flame photometer method was used for determination of $\mathrm{Na}^{+}$ and $\mathrm{K}^{+}$.

\section{Statistical analysis}

Mean and mean differences were used as a descriptive statistical analysis method. One-way ANOVA was used to test whether there is a significant difference in soil physicochemical properties between conserved and nonconserved plots. Two-way ANOVA was applied to test whether soil properties are affected significantly due to the interaction effect of land uses and SWC treatment. In addition, bivariate correlation analysis was used to show the relationships between soil physicochemical properties. The statistical analysis was manipulated using Statistical Package for Social Scientists [SPSS] version 20.

\section{Results}

The effects of SWC initiatives practiced through free labor communities' mass-mobilization on selected soil physicochemical properties (bulk density, soil texture, soil $\mathrm{pH}$, total nitrogen, organic carbon, available phosphorous, cation exchange capacity (CEC), and exchangeable basis) were evaluated using mean differences and ANOVA. Furthermore, the assumptions of ANOVA were tested using Levene's test of homogeneity and Shapiro-Wilk test of normality (Table 1 ).

The test of normality for SOC, av. P, clay, and silt content of the soil were found significant, which indicates non-normal distribution $(p<0.05$; Table 1$)$. In this regard, Blanca et al. (2017) and Stevens (2007) reported the robustness of $F$ test for non-normally distributed data $(p<0.05)$. Therefore, the robust test of ANOVA result was used for dependent variables showing non-normally distribued data. The homogeneity of variance assumption of one-way ANOVA for TN was violated $(p<0.05)$ in the data collected from treated and untreated cultivated plots. In this case, the robust test (Welch) were used; as the Welch test is the best method for homogeneous but normal and balanced data to control type I error (Liu 2015; Stevens 2007).

\section{The effect of soil and water conservation practices on soil physical properties \\ Soil particle size proportions (distributions)}

The textural classes were identified using soil equilateral triangle recommended by USDA and described by Osman (2013). Accordingly, the mean particle size proportion showed that the soil was fine textured in conserved and non-conserved plots. The soil in the study area has been dominated by clay content experiencing a mean value of $67.8 \%$ and $60.5 \%$ in conserved and nonconserved soil respectively (Table 2 ), which implies that the mean value of clay content was higher under conserved plots. The mean sand fraction is the lowest proportion of soil particle content in the area. It was also indicated that the mean sand fraction was relatively lower in conserved plots. This might be attributed to the relative effect of SWC on soil erosion, which reduces the removal of top fine soil particles. On the contrary, higher sand content of the soil in non-conserved plots may be resulted due to removal of fine particles via soil erosion. A land that receives a high amount of rainfall and continuously cultivated without any conservation measure could allow free and easy removal of fine particles via rainfall runoff.

The silt content of the soil was higher in non-conserved plots against the conserved plots. However, the differences in the mean soil particle size distribution (sand, clay, and silt) among conserved and non-conserved plots were not statistically significant at $p<0.05$ (Table 2).

\section{Soil bulk density}

The effect of SWC on the mean soil bulk density was found to be minimal and slightly lower values were observed in conserved plots. A relatively higher bulk density in non-conserved plots could be related with washing out of fine organic matter rich soils by erosion and thereby exposed slightly heavier soil particulates. The ANOVA result indicated that the variation in bulk density was not statistically significant following treatment $(p<0.05$; Table 2). 
Table 1 Test of normality and homogeneity of variance for soil physical and chemical properties in both land uses and per land use types

\begin{tabular}{|c|c|c|c|c|c|c|c|}
\hline \multirow[t]{2}{*}{ Soil properties } & & \multicolumn{2}{|c|}{$\underline{\text { Both land uses }(n=24)}$} & \multicolumn{2}{|c|}{ Cultivated land $(n=12)$} & \multicolumn{2}{|c|}{ Grazing land $(n=12)$} \\
\hline & & Levene's $(p)$ & Shapiro-Wilk $(p)$ & Levene's $(p)$ & Shapiro-Wilk $(p)$ & Levene's $(p)$ & Shapiro-Wilk (p) \\
\hline \multicolumn{2}{|l|}{$\mathrm{pH}\left(\mathrm{H}_{2} \mathrm{O}\right)$} & $.35^{n s}$ & $394^{\text {ns }}$ & $.627^{\mathrm{ns}}$ & $.400^{\mathrm{ns}}$ & $.318^{\mathrm{ns}}$ & $.462^{\mathrm{ns}}$ \\
\hline \multicolumn{2}{|l|}{ SOC (\%) } & $.272^{\mathrm{ns}}$ & $.002^{*}$ & $.496^{\mathrm{ns}}$ & $.629^{\mathrm{ns}}$ & $.111^{\mathrm{ns}}$ & $.152^{\mathrm{ns}}$ \\
\hline \multicolumn{2}{|l|}{ TN (\%) } & $.172^{\mathrm{ns}}$ & $.098^{\text {ns }}$ & $.019^{*}$ & $.419^{\mathrm{ns}}$ & $.143^{\mathrm{ns}}$ & $.941^{\text {ns }}$ \\
\hline \multicolumn{2}{|l|}{ Bulk density $\left(\mathrm{g} \mathrm{cm}^{-3}\right)$} & $.269^{\mathrm{ns}}$ & $.102^{\mathrm{ns}}$ & $.507^{\mathrm{ns}}$ & $.487^{\mathrm{ns}}$ & $.645^{\mathrm{ns}}$ & $.659^{\mathrm{ns}}$ \\
\hline \multicolumn{2}{|l|}{ Sand (\%) } & $.446^{\mathrm{ns}}$ & $.053^{\mathrm{ns}}$ & $.285^{\mathrm{ns}}$ & $.661^{\mathrm{ns}}$ & $.086^{\mathrm{ns}}$ & $.139^{\mathrm{ns}}$ \\
\hline \multicolumn{2}{|l|}{ Clay (\%) } & $.811^{\text {ns }}$ & $.021^{*}$ & $.391^{\mathrm{ns}}$ & $.084^{\text {ns }}$ & $.331^{\mathrm{ns}}$ & $.117^{\text {ns }}$ \\
\hline \multicolumn{2}{|l|}{ Silt (\%) } & $.571^{\mathrm{ns}}$ & $.049^{\mathrm{ns}}$ & $.467^{\mathrm{ns}}$ & $.042^{*}$ & $.080^{\mathrm{ns}}$ & $.036^{*}$ \\
\hline \multicolumn{2}{|l|}{ Av. P (ppm) } & $.433^{\text {ns }}$ & $.014^{*}$ & $.468^{\mathrm{ns}}$ & $.605^{\mathrm{ns}}$ & $.972^{\mathrm{ns}}$ & $.517^{\mathrm{ns}}$ \\
\hline \multirow[t]{5}{*}{ CEC \& Exch. cations $\left[\mathrm{cmol}(+) \mathrm{kg}^{-1}\right]$} & CEC & $.608^{\text {ns }}$ & $.091^{\text {ns }}$ & $.919^{\mathrm{ns}}$ & $.391^{\text {ns }}$ & $.425^{\mathrm{ns}}$ & $.219^{\mathrm{ns}}$ \\
\hline & $\mathrm{Na}^{+}$ & $.091^{\text {ns }}$ & $.808^{\text {ns }}$ & $.475^{\mathrm{ns}}$ & $.987^{\text {ns }}$ & $.104^{\text {ns }}$ & $.770^{\text {ns }}$ \\
\hline & $\mathrm{K}^{+}$ & $.83^{\mathrm{ns}}$ & $.223^{\mathrm{ns}}$ & $.907^{\mathrm{ns}}$ & $.071^{\mathrm{ns}}$ & $.797^{\mathrm{ns}}$ & $.910^{\mathrm{ns}}$ \\
\hline & $\mathrm{Ca}^{2+}$ & $.972^{\mathrm{ns}}$ & $.147^{\mathrm{ns}}$ & $.876^{\mathrm{ns}}$ & $.200^{\mathrm{ns}}$ & $.934^{\mathrm{ns}}$ & $.102^{\mathrm{ns}}$ \\
\hline & $\mathrm{Mg}^{2+}$ & $.614^{\text {ns }}$ & $.474^{\mathrm{ns}}$ & $.898^{\mathrm{ns}}$ & $.545^{\mathrm{ns}}$ & $.360^{\mathrm{ns}}$ & $.425^{\mathrm{ns}}$ \\
\hline
\end{tabular}

Av. $P$ available phosphorous, CEC cation exchange capacity, $n s$ not significant at $p<0.05, n$ number of samples, $P p$ value, SOC soil organic carbon, ${ }^{*}$ significant at $p<0.05, T N$ total nitrogen

The effect of soil and water conservation practices on soil chemical properties

\section{Soil reaction (soil $\mathrm{pH}$ )}

The acidity level of the watershed in general was rated as medium acidic based on Osman (2013) acidity and alkalinity categories of soil $\mathrm{pH}$. The mean $\mathrm{pH}$ of the soil in the study watershed was 5.77 and 5.66 in conserved and non-conserved land respectivly (Table 3 ). The acidity of the soil could be related with its sub-humid nature of the area and high amount of rainfall. This is true that greater rainfall increases soil acidity and humid areas are more acidic than arid and semi-arid areas (Osman 2013).

\section{Soil organic carbon (SOC) and soil organic matter (SOM)}

The analysis of variance result for SOC and SOM showed a statistically significant mean difference following treatments $(p<0.05$; Table 3$)$. The mean organic carbon and organic matter content of the soil in conserved plots were higher $(\mathrm{SOC}=2.49 \%, \mathrm{SOM}=4.3 \%$ ) than non-conserved plots ( $\mathrm{SOC}=1.66 \%, \mathrm{SOM}=2.83 \%$ ). Besides, the mean soil organic carbon (SOC) content was rated low in conserved and very low in non-conserved plots according to the rating standard developed for tropical soils (Landon 2013). It could be explained by soil erosion, continuous cultivation, harvesting crop residues, and animal dung. The use of animal dung for fuel instead of manure may reduce the effectiveness of SWC practices in SOC concentration (Mengistu et al. 2016).

\section{Total nitrogen}

The total nitrogen (TN) content of the soil was significantly affected by SWC practices ( $p<0.01$; Table 3$)$. TN content of the soil in Gumara watershed was rated medium and low in conserved and non-conserved plots respectively (Landon 2013). The mean total nitrogen of the soil was greater in conserved $(0.27 \%)$ than non-conserved plots $(0.138 \%)$.

Table 2 The mean and their significant variations (one-way ANOVA) of soil physical properties in conserved and non-conserved plots

\begin{tabular}{|c|c|c|c|c|c|c|c|}
\hline & & \multicolumn{3}{|c|}{ Soil particle size proportions } & \multirow{2}{*}{$\begin{array}{l}\text { Soil } \\
\text { texture }\end{array}$} & \multirow{2}{*}{$\begin{array}{l}\text { Soil } \\
\text { textural } \\
\text { class }\end{array}$} & \multirow{2}{*}{$\begin{array}{l}\text { Bulk } \\
\text { density } \\
\left(\mathrm{g} \mathrm{cm}^{-3}\right.\end{array}$} \\
\hline & & Sand (\%) & Clay (\%) & Silt (\%) & & & \\
\hline \multirow[t]{4}{*}{ Treatment } & $\mathrm{CL}$ & 7.83 & 67.8 & 24.3 & Fine & Clay & 1.250 \\
\hline & $\mathrm{NCL}$ & 10.3 & 60.5 & 29.2 & Fine & Clay & 1.247 \\
\hline & F ratio & .864 & 1.914 & 1.258 & Fine & Clay & .002 \\
\hline & $p$ & $.363^{\text {ns }}$ & $.18^{\text {ns }}$ & $.274^{\mathrm{ns}}$ & - & - & $.963^{\mathrm{ns}}$ \\
\hline
\end{tabular}

$C L$ conserved land, NCL non-conserved land, $P p$ value, ns not significant at $p<0.05$ 
Table 3 The mean and their significant variations (one-way ANOVA) of soil chemical properties in conserved and non-conserved plots

\begin{tabular}{|c|c|c|c|c|c|c|c|c|c|c|c|}
\hline & & \multirow{2}{*}{$\begin{array}{l}\mathrm{pH} \\
\left(\mathrm{H}_{2} \mathrm{O}\right)\end{array}$} & \multirow{2}{*}{$\begin{array}{l}\text { SOC } \\
(\%)\end{array}$} & \multirow{2}{*}{$\begin{array}{l}\text { SOM } \\
(\%)\end{array}$} & \multirow{2}{*}{$\begin{array}{l}\text { TN } \\
(\%)\end{array}$} & \multirow{2}{*}{$\begin{array}{l}\text { Av. P } \\
\text { (ppm) }\end{array}$} & \multicolumn{5}{|c|}{ CEC and Exch. cations $\left[\mathrm{cmol}(+) \mathrm{kg}^{-1}\right]$} \\
\hline & & & & & & & $\overline{\mathrm{CEC}}$ & $\mathrm{Na}^{+}$ & $\mathrm{K}^{+}$ & $\mathrm{Ca}^{2+}$ & $\mathrm{Mg}^{2+}$ \\
\hline \multirow[t]{4}{*}{ Treatment } & $\mathrm{CL}$ & 5.77 & 2.49 & 4.3 & .270 & 6.96 & 33.6 & .31 & .52 & 19.3 & 8.68 \\
\hline & $\mathrm{NCL}$ & 5.66 & 1.66 & 2.86 & .138 & 7.9 & 31.9 & .18 & .46 & 21.4 & 5.87 \\
\hline & F ratio & .772 & 4.457 & 4.457 & 8.504 & .353 & .195 & 12.36 & .361 & .425 & 9.515 \\
\hline & $p$ & $.389^{\mathrm{ns}}$ & $.046^{*}$ & $.046^{*}$ & $.008^{* *}$ & $.558^{\mathrm{ns}}$ & $.663^{\mathrm{ns}}$ & $.002^{* *}$ & $.554^{\mathrm{ns}}$ & $.521^{\mathrm{ns}}$ & $.005^{* *}$ \\
\hline
\end{tabular}

Av. $P$ available phosphorous, CEC cation exchange capacity, CL conserved land, NCL non-conserved land, $n$ s not significant at $p<0.05, P p$ value, SOC soil organic carbon, SOM soil organic matter; **** significantly different at $p<0.01$ and $p<0.05$ respectively (two-tailed); $T N$ total nitrogen

\section{Available phosphorous}

Available phosphorous of the soil was not significantly affected by conservation measures $(p>0.05)$. Its mean value was lower in conserved plots (6.96 ppm) as compared to non-conserved plots (7.9 ppm) (Table 3). The varations in the use of artificial fertilizer (diammonium phosphate) may be the reason for the previaled varations in the soil. As compared to the requirements of crops that have been dominantly practiced in the area, the phosphorous content of the soil was questionable (4.1$8 \mathrm{ppm})$ and deficient $(<11 \mathrm{ppm})$ for low demand crops (such as cereals and maize) and high demand crops (such as potatoes, onions) respectively (Landon 2013).

\section{Cation exchange capacity}

According to the rating standards of Landon (2013), the cation exchange capacity (CEC) of the soil in Gumara watershed was rated as high $\left(25-40 \mathrm{cmol}(+) \mathrm{kg}^{-1}\right)$ in both conserved and non-conserved plots. The study result revealed that SWC measures had a positive effect on the CEC content of the soil. The mean difference was higher in conserved plots $\left(33.6 \mathrm{cmol}(+) \mathrm{kg}^{-1}\right)$ than non-conserved plots $\left(31.9 \mathrm{cmol}(+) \mathrm{kg}^{-1}\right)$ (Table 3$)$, but not statistically significant $(p>0.05)$. This is believed to be caused by the relative effect of conservation measures in the watershed.

\section{Exchangeable cations $\left(\mathrm{Na}^{+}, \mathrm{K}^{+}, \mathrm{Ca}^{2+}\right.$, and $\left.\mathrm{Mg}^{2+}\right)$}

The relative abundance of basic cations in the exchange complex was $\mathrm{Na}^{+}<\mathrm{K}^{+}<\mathrm{Mg}^{2+}<\mathrm{Ca}^{2+}$ for both conserved and non-conserved soils. Exchangeable $\mathrm{Ca}^{2+}$ (19.3 $\left.\mathrm{cmol}(+) \quad \mathrm{kg}^{-1}, \quad 21.4 \mathrm{cmol}(+) \quad \mathrm{kg}^{-1}\right)$ and $\mathrm{Na}^{+}$ $\left(0.31 \mathrm{cmol}(+) \mathrm{kg}^{-1}, 0.18 \mathrm{cmol}(+) \mathrm{kg}^{-1}\right)$ constitutes the highest and lowest proportion in conserved and nonconserved plots respectively (Table 3 ). One-way analysis of variance result for exchangeable $\mathrm{Na}^{+}$and $\mathrm{Mg}^{2+}$ showed a statistically significant difference $(p<0.01)$ between conserved and non-conserved plots. By contrast, the effect of conservation practices for exchangeable $\mathrm{Ca}^{2+}$ and $\mathrm{K}^{+}$was not statistically significant $(p>0.05)$.

\section{The effectivness of conservation practices in different land uses}

As shown in Table 4, the analysis of variance result for the mean differences of all soil particle size distributions was not significantly affected by conservation practices in both land uses $(p>0.05)$. However, mean differences were observed in cultivated and grazing land uses following treatments. The highest sand fraction was recorded from non-conserved cultivated land and lowest in conserved grazing land. The mean clay content of the soil was $65.67 \%$ and $62 \%$ in conserved and non-conserved cultivated plots.

The mean difference for bulk density was slightly higher in cultivated land, with higher mean values in the non-conserved than in the conserved land (Table 4). It was not the case for grazing land uses, in which conserved plots experience higher mean values than nonconserved plots. The ANOVA result indicated that the variation in bulk density was not statistically significant between the conserved and non-conserved lands for either cultivated or grazing land uses due to SWC treatment ( $p>0.05$; Table 4).

The influence of land use on the effect of conservation measures for the mean difference of soil $\mathrm{pH}$ was slight. Higher SOC concentration was observed in grazing land uses than in cultivated land uses. Our analysis result by land use revealed that the mean difference in SOC and SOM was higher and statistically significant $(p<0.05)$ between conserved and non-conserved cultivated land uses.

Higher TN content of the soil was observed in conserved grazing land uses $(0.32 \%)$ followed by conserved cultivated land uses $(0.219 \%)$ and non-conserved cultivated lands constitute the lowest $(0.105 \%)$ (Table 5$)$. The ANOVA result revealed a significant effect on effectiveness of conservation measures on cultivated plots at $p<$ 0.01. Conversely, conservation measures did not show a statistically significant variation for SOM, SOC, and TN in grazing lands $(p<0.05)$.

The SWC treatments for available phosphorous were not significantly affected by land uses $(p>0.05)$. Instead, greater concentrations were observed in non-conserved $(9.755 \mathrm{ppm})$ than in conserved cultivated land 
Table 4 The effect of SWC practices on soil physical properties in different land uses (cultivated and grazing land)

\begin{tabular}{|c|c|c|c|c|c|c|c|}
\hline & & \multicolumn{3}{|c|}{ Soil particle size proportions } & \multirow{2}{*}{$\begin{array}{l}\text { Soil } \\
\text { texture }\end{array}$} & \multirow{2}{*}{$\begin{array}{l}\text { Soil } \\
\text { textural } \\
\text { class }\end{array}$} & \multirow{2}{*}{$\begin{array}{l}\text { Bulk } \\
\text { density } \\
\left(\mathrm{g} \mathrm{cm}^{-3}\right)\end{array}$} \\
\hline & & Sand (\%) & Clay (\%) & Silt (\%) & & & \\
\hline \multirow[t]{4}{*}{ Cultivated land } & $\mathrm{CL}$ & 9.333 & 65.67 & 25 & Fine & Clay & 1.29 \\
\hline & $\mathrm{NCL}$ & 11 & 62 & 27 & Fine & Clay & 1.318 \\
\hline & F ratio & .312 & .258 & .098 & Fine & Clay & .846 \\
\hline & $p$ & $.589^{\mathrm{ns}}$ & $.623^{\mathrm{ns}}$ & $.76^{\mathrm{ns}}$ & - & - & $.379^{\text {ns }}$ \\
\hline \multirow[t]{4}{*}{ Grazing land } & $\mathrm{CL}$ & 6.33 & 70 & 23.7 & Fine & Clay & 1.21 \\
\hline & $\mathrm{NCL}$ & 9.67 & 59 & 31.3 & Fine & Clay & 1.18 \\
\hline & F ratio & .509 & 1.76 & 1.509 & Fine & Clay & .122 \\
\hline & $p$ & $.492^{\mathrm{ns}}$ & $.214^{\mathrm{ns}}$ & $.247^{\mathrm{ns}}$ & - & - & $.734^{\mathrm{ns}}$ \\
\hline
\end{tabular}

$C L$ conserved land, NCL non-conserved land, $P p$ value, ns not significant at $p<0.05$

(7.78 ppm) (Table 5). Grazing land uses revealed very small mean difference for available phosphorous following SWC treatments. The use of inorganic fertilizer (diammonium phosphate) to enhance crop production in cultivated land could probably increase av. P concentrations in cultivated plots.

The CEC content of the soil in conserved and non-conserved land uses revealed $31.97 \mathrm{cmol}(+) \mathrm{kg}^{-1}$, $35.3 \mathrm{cmol}(+) \quad \mathrm{kg}^{-1}$ in cultivated land and $29.56 \mathrm{cmol}(+) \mathrm{kg}^{-1}, 34.3 \mathrm{cmol}(+) \mathrm{kg}^{-1}$ in grazing land respectively (Table 5). The influence of conservation structures on CEC was not determined by land uses and the mean difference was not statistically significant for both land uses. However, the impact of SWC has been better in cultivated land uses as compared to grazing land uses. The effect of SWC in cultivated and grazing land uses showed a statistically significant difference in exchangeable $\mathrm{Na}^{+}$for both land uses $(p<0.05)$ and exchangeable $\mathrm{Mg}^{2+}$ only in cultivated land use $(p<0.01)$.

A two-way between groups analysis of variance was conducted to explore the impact of SWC treatment and land use types on soil fertility variation. The result showed a statistically significant main effect for SWC treatment on SOC, SOM at $p<0.05$, and $\mathrm{TN}, \mathrm{Na}^{+}$, and $\mathrm{Mg}^{2+}$ at $p<0.01$. The main effect for land uses was statistically significant only for SOC, SOM, and bulk density at $p<0.05$. However, the interaction effect of SWC treatment and land uses did not show a statistically significant mean difference for any of the selected soil fertility indicators $(p<0.05$; Table 6$)$.

\section{The interrelationship among soil physicochemical properties}

The simple linear correlation (Pearson) results revealed the strength and magnitude of relationship among physicochemical properties. The $\mathrm{pH}$ of the soil showed a positive significant relationship with SOM $\left(0.673^{* *}\right)$, TN $\left(0.628^{* *}\right)$, CEC $\left(0.619^{* *}\right)$, and all exchangeable bases except magnesium (Table 7$)$. It also showed significantly negative relationship with $\mathrm{BD}\left(-0.426^{*}\right)$. The correlation matrix further revealed a positive very strong significant relationship $\left(0.959^{* * *}\right)$ between TN and SOM and strong

Table 5 The effect of SWC practices on soil chemical properties in different land uses (cultivated and grazing land)

\begin{tabular}{|c|c|c|c|c|c|c|c|c|c|c|c|}
\hline & & \multirow{2}{*}{$\begin{array}{l}\mathrm{pH} \\
\left(\mathrm{H}_{2} \mathrm{O}\right)\end{array}$} & \multirow{2}{*}{$\begin{array}{l}\text { SOC } \\
(\%)\end{array}$} & \multirow{2}{*}{$\begin{array}{l}\text { SOM } \\
(\%)\end{array}$} & \multirow{2}{*}{$\begin{array}{l}\text { TN } \\
(\%)\end{array}$} & \multirow{2}{*}{$\begin{array}{l}\text { Av. P } \\
\text { (ppm) }\end{array}$} & \multicolumn{5}{|c|}{ CEC and Exch. cations $\left[\mathrm{cmol}(+) \mathrm{kg}^{-1}\right]$} \\
\hline & & & & & & & $\overline{C E C}$ & $\mathrm{Na}^{+}$ & $\mathrm{K}^{+}$ & $\mathrm{Ca}^{2+}$ & $\mathrm{Mg}^{2+}$ \\
\hline \multirow[t]{4}{*}{ Cultivated land } & $C L$ & 5.712 & 2.027 & 3.494 & .219 & 7.778 & 31.97 & .305 & .562 & 17.13 & 8.817 \\
\hline & $\mathrm{NCL}$ & 5.6 & 1.248 & 2.152 & .105 & 9.755 & 29.56 & .178 & .463 & 19.1 & 5.25 \\
\hline & F ratio & .316 & 11.577 & 11.577 & 12.607 & .474 & .301 & 5.346 & .545 & .223 & 14.101 \\
\hline & $p$ & $.586^{\mathrm{ns}}$ & $.007^{* *}$ & $.007^{* *}$ & $.005^{* *}$ & $.507^{\mathrm{ns}}$ & $.595^{\mathrm{ns}}$ & $.043^{*}$ & $.477^{\mathrm{ns}}$ & $.647^{\mathrm{ns}}$ & $.004^{* *}$ \\
\hline \multirow[t]{4}{*}{ Grazing land } & $C L$ & 5.82 & 2.96 & 5.1 & .320 & 6.13 & 35.3 & .32 & .47 & 21.4 & 8.55 \\
\hline & $\mathrm{NCL}$ & 5.72 & 2.07 & 3.56 & .172 & 6.05 & 34.3 & .18 & .47 & 23.7 & 6.48 \\
\hline & $F$ ratio & .461 & 1.647 & 1.647 & 3.408 & .006 & .021 & 5.93 & .003 & .205 & 1.638 \\
\hline & $p$ & $.512^{\mathrm{ns}}$ & $.228^{\mathrm{ns}}$ & $.228^{\mathrm{ns}}$ & $.095^{\mathrm{ns}}$ & $.941^{\mathrm{ns}}$ & $.886^{\mathrm{ns}}$ & $.035^{*}$ & $.958^{\text {ns }}$ & $.66^{\mathrm{ns}}$ & $.229^{\mathrm{ns}}$ \\
\hline
\end{tabular}

$A v$. $P$ available phosphorous, CEC cation exchange capacity, $C L$ conserved land, NCL non-conserved land, $n s$ not significant at $p<0.05, P p$ value, SOC soil organic carbon, SOM soil organic matter; ${ }^{* *},{ }^{*}$ significantly different at $p<0.01$ and $p<0.05$ respectively (two-tailed); $T N$ total nitrogen 
Table 6 The two-way ANOVA result showing the interacton effect of land uses and SWC treatment on soil physicochemical properties

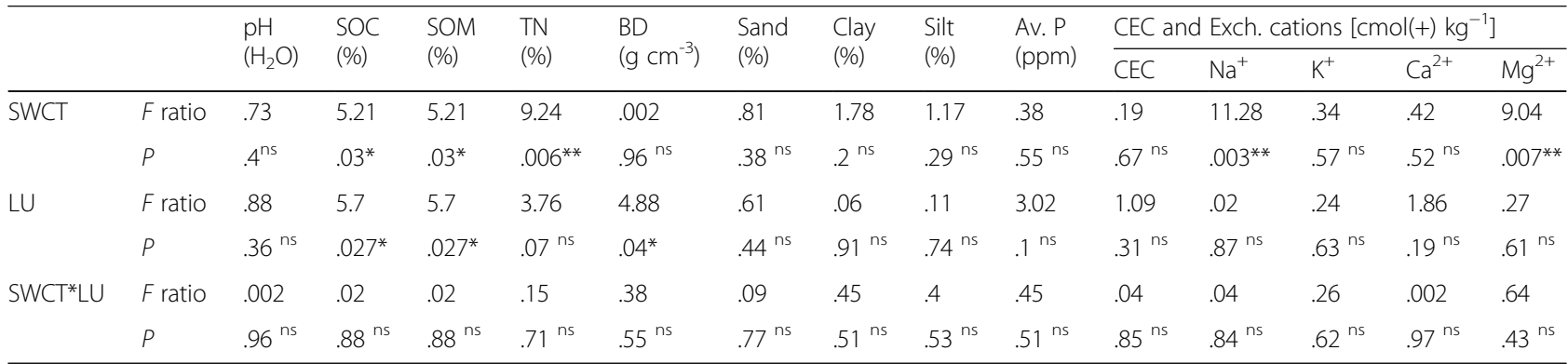

Av. $P$ available phosphorous, $B D$ bulk density, CEC cation exchange capacity, $L U$ land use, $n$ s not significant at $p<0.05, P p$ value, SOC soil organic carbon, SOM soil organic matter; **** significantly different at $p<0.01$ and $p<0.05$ respectively (two-tailed); SWCT soil and water conservation treatment, TN total nitrogen

positive significant correlation $\left(0.7^{* * *}, 0.783^{* * *}, 0.734^{* *}\right)$ with CEC, exchangeable $\mathrm{Na}^{+}$, and $\mathrm{Mg}^{2+}$ content.

Similarly, bulk density showed strong negative significant relationship $\left(-0.702^{* *},-0.756^{* *},-0.747^{* *}\right)$ with $\mathrm{OM}, \mathrm{CEC}$, and exchangeable $\mathrm{Ca}^{2+}$ content of the soil respectively. However, available phosphorous showed no regular trends and weakly varied with other soil physicochemical properties in Gumara watershed (Table 7).

\section{Discussion}

The impact of soil and water conservation practices on soil properties

SWC measures implemented in the Gumara watershed have improved the soil condition as a result of reduction in runoff and sediment transport. This is indicated by the significant variations in soil physicochemical properties between conserved and non-conserved plots. SWC structures decreased the slope length and steepness and consequently led to better infiltration, slow movement, and less accumulation of runoff. As a result, the removal of soil particles, crop residues, and other organic components can be limited, which improves the soil condition as compared to the non-conserved soils.

The particle size proportion of the soil was fine textured in both conserved and non-conserved soils. The soil of the watershed was dominated by clay content indicating relatively higher mean value in conserved plots. Similarly, Mengistu et al. (2016) reported higher mean clay content in the conserved Minchit than in non-conserved Zikire sub-watershed. Higher soil erosion, removal of fine materials, clay contents, and organic

Table 7 The relationship (Pearson's product movement coefficient of correlation) between soil physicochemical properties

\begin{tabular}{|c|c|c|c|c|c|c|c|c|c|c|c|c|c|c|c|}
\hline \multirow[t]{2}{*}{ Soil properties } & & \multirow{2}{*}{$\begin{array}{l}\mathrm{pH} \\
\left(\mathrm{H}_{2} \mathrm{O}\right)\end{array}$} & \multirow{2}{*}{$\begin{array}{l}\text { SOC } \\
(\%)\end{array}$} & \multirow{2}{*}{$\begin{array}{l}\text { SOM } \\
(\%)\end{array}$} & \multirow[t]{2}{*}{ TN (\%) } & \multirow{2}{*}{$\begin{array}{l}\mathrm{BD} \\
\left(\mathrm{g} \mathrm{cm}^{-3}\right)\end{array}$} & \multirow{2}{*}{$\begin{array}{l}\text { Sand } \\
(\%)\end{array}$} & \multirow{2}{*}{$\begin{array}{l}\text { Clay } \\
(\%)\end{array}$} & \multirow{2}{*}{$\begin{array}{l}\text { Silt } \\
(\%)\end{array}$} & \multirow{2}{*}{$\begin{array}{l}\text { Av. P } \\
\text { (ppm) }\end{array}$} & \multicolumn{5}{|c|}{ CEC and Exch. cations $\left[\mathrm{cmol}^{(+)} \mathrm{kg}^{-1}\right]$} \\
\hline & & & & & & & & & & & CEC & $\mathrm{Na}^{+}$ & $\mathrm{K}^{+}$ & $\mathrm{Ca}^{2+}$ & $\mathrm{Mg}^{2+}$ \\
\hline $\mathrm{pH}\left(\mathrm{H}_{2} \mathrm{O}\right)$ & & 1 & & & & & & & & & & & & & \\
\hline SOC (\%) & & $.673^{* *}$ & 1 & & & & & & & & & & & & \\
\hline SOM (\%) & & $.673^{* *}$ & $1.000^{* *}$ & 1 & & & & & & & & & & & \\
\hline TN (\%) & & $.628^{* *}$ & $.959^{* *}$ & $.959^{* *}$ & 1 & & & & & & & & & & \\
\hline $\mathrm{BD}\left(\mathrm{g} \mathrm{cm}^{-3}\right)$ & & $-.426^{*}$ & $-.702^{* *}$ & $-.702^{* *}$ & $-.661^{* *}$ & 1 & & & & & & & & & \\
\hline Sand (\%) & & -.248 & -.403 & -.403 & $-.481^{*}$ & $.598^{* *}$ & 1 & & & & & & & & \\
\hline Clay (\%) & & .230 & .354 & .354 & $.461^{*}$ & $-.417^{*}$ & $-.608^{* *}$ & 1 & & & & & & & \\
\hline Silt (\%) & & -.133 & -.192 & -.192 & -.277 & .150 & .140 & $-.871^{* *}$ & 1 & & & & & & \\
\hline Av. P (ppm) & & .232 & -.221 & -.221 & -.227 & .212 & .029 & .102 & -.145 & 1 & & & & & \\
\hline \multirow{5}{*}{$\begin{array}{l}\text { CEC \& Exch. } \\
\text { cations } \\
{\left[\mathrm{cmol}(+) \mathrm{kg}^{-1}\right]}\end{array}$} & CEC & $.619^{* *}$ & $.765^{* *}$ & $.765^{* *}$ & $.699^{* *}$ & $-.756^{* *}$ & $-.425^{*}$ & .339 & -.160 & .083 & 1 & & & & \\
\hline & $\mathrm{Na}^{+}$ & $.640^{* *}$ & $.756^{* *}$ & $.756^{* *}$ & $.783^{* *}$ & $-.496^{*}$ & $-.504^{*}$ & $.463^{*}$ & -.266 & .093 & $.763^{* *}$ & 1 & & & \\
\hline & $\mathrm{K}^{+}$ & .188 & .115 & .115 & .082 & -.228 & -.257 & -.130 & .321 & -.053 & .232 & .331 & 1 & & \\
\hline & $\mathrm{Ca}_{2}{ }^{+}$ & $.669^{* *}$ & $.641^{* *}$ & $.641^{* *}$ & $.553^{* *}$ & $-.747^{* *}$ & $-.428^{*}$ & .261 & -.061 & .183 & $.931^{* *}$ & $.621^{* *}$ & .179 & 1 & \\
\hline & $\mathrm{Mg}_{2}^{+}$ & $.505^{*}$ & $.741^{* *}$ & $.741^{* *}$ & $.734^{* *}$ & $-.501^{*}$ & -.304 & .295 & -.180 & -.073 & $.768^{* *}$ & $.807^{* *}$ & .380 & $.529^{* *}$ & 1 \\
\hline
\end{tabular}

Av. $P$ available phosphorous, BD bulk density, CEC cation exchange capacity, SOC soil organic carbon, SOM soil organic matter; ${ }^{* *}{ }^{*}$ the correlation is significant at $p<0.01$ and $p<0.05$ respectively (two-tailed); $T N$ total nitrogen 
matter could be possible reasons for relativly lower clay content in non-conserved plots.

Clay contents are fine particulates and more vulnerable to be washed out by erosion unless treated with SWC measures (Hishe et al. 2017; Selassie et al. 2015). A clay soil has an inherent advantage of good water and nutrient holding capacity and low level of leaching (Osman 2013). This nature of the soil helps the area to be more productive, even though it has been influenced by high soil erosion, continuous cultivation, and other natural and manmade influences. However, significant variation was not observed between conserved and non-conserved plots. This might be related with the prevailing parent materials and its inherent properties; such nature of the soil determines the texture of a soil, even if erosion, deposition, and other human activities may modify (Osman 2013).

SWC practices affected the bulk density of the soil in Gumara watershed. A relatively higher bulk density in non-conserved plots could be related with washing out of fine organic matter-rich soils by erosion and thereby exposing slightly heavier soil particles. On the other side, several potential causes may explain lower bulk density in conserved plots such as lesser effects of soil erosion (SWC structures as a barrier) and relatively higher SOM content resulted from accumulation of crop residues decay, plant leaves' decay, and less vulnerability for easy removal of this components. The study finding was consistent with the results reported by Hishe et al. (2017) and Hailu et al. (2012) for Middle Silluh valley, northern Ethiopia, and Goromti watershed western Ethiopia respectively. On the other hand, Challa et al. (2016), Husen et al. (2017), and Selassie et al. (2015) reported a statistically significantly lower bulk density in conserved plots than in non-conserved plots.

Soil $\mathrm{pH}$ showed slightly higher mean values in conserved plots. Relatively higher soil acidity in non-conserved plots may be related with high rainfall, associated with leaching and removal of important soil nutrients. Amare et al. (2013) and Osman (2013) explained that high amount of rain water leaches soluble bases and consequently contributes to soil acidity. Similarly, longterm cropping, high rainfall, topographic steepness, and the application of inorganic fertilizer could probably increase soil acidity (Selassie et al. 2015). The analysis of variance result show that soil $\mathrm{pH}$ was not statistically significantly affected by conservation practices (Table 3). Similar results were reported by Challa et al. (2016) and Husen et al. (2017) in the central highland of Ethiopia.

The effect of conservation measures on SOC, SOM, and TN has been significant in the watershed. This coincides with Challa et al. (2016), Hailu et al. (2012), Hishe et al. (2017), Selassie et al. (2015), and Sinore et al. (2018), who reported statistically significantly higher SOC in terraced landscapes. It could be mainly related with conservation structures and biomass accumulation (Selassie et al. 2015). Soils exposed for severe erosion has been more vulnerable to decomposition of SOC than slightly eroded soils (Abegaz et al. 2016). This implies that non-conserved soils are more vulnerable to erosion and most likely to have low SOC concentration as compared to conserved soils.

As a result, supporting SWC structures by agro-forestry practice has been suggested for better carbon sequestration in the soil (Abegaz et al. 2016; Degefu et al. 2011). Similarly, supporting terracing with susbania and elephant grasses could result in high SOC and SOM due to high biomass return, which contributes to symbiotic fixation and soil erosion reduction (Sinore et al. 2018). However, we identified during on-site observation that as an agro-forestry and gully rehabilitation system, eucalyptus tree plantations were predominantly used to limit soil erosion and other related benefits in the study watershed. However, it was reported that the use of eucalyptus tree limits undergrowth and its contribution for SWC has been poor (Fikreyesus et al. 2011) and it is highly nutrient and water consuming species (Wolancho 2015). Hence, there is a need to recommend other better alternative tree plantations in the area.

The variation is primarily explained by conservation effects on soil erosion, because soil bund reduces loss of fine soil particles and residues (Husen et al. 2017; Mengistu et al. 2016; Selassie et al. 2015; Sinore et al. 2018). This process further improves the concentration of SOM and SOC which consequently leads to increase TN in the soil. The result was consistent with Challa et al. (2016), Hailu et al. (2012), Husen et al. (2017), Selassie et al. (2015), and Sinore et al. (2018), who stated that conserved plots resulted in significantly higher TN content. On the other side, the result did not agree with the findings of Hishe et al. (2017) who reported statistically non-significant difference in plots following treatments.

The available phosphorous content of the soil between conserved and non-conserved plots did not have consistent pattern with conservation measures. The application of diammonium phosphate (DAP) may be the reason for its indistinguishable availability in the soil. This result coincides with the result reported by Hishe et al. (2017) for Middle Silluh valley, Northern Ethiopia. Hailu et al. (2012) did not find a statistically significant difference between treated and non-treated fields. Our result was not in agreement with Mengistu et al. (2016) and Selassie et al. (2015) who observed insignificant but higher available phosphorous concentration in conserved soils.

The concentration of av. P in the soil in Gumara watershed was deficient. This could be explained by different factors; the medium acidity nature of the soil and soil erosion through runoff may contribute to its limited availability in the soil. The limited availability of 
phosphorous in the soil may limit the growth and productivity of plants in the area. Phosphorous in the soil is highly required by plants and may cause slow growth when its concentration is very low (Hishe et al. 2017).

The CEC and exchangeable basis content of the soil in the watershed was rated as high. This might be due to the inherent characteristics of the soil because fine textured soils have more exchangeable basis (Osman 2013). Soils having high clay and SOM content have strong probability to hold positively charged ions and consequently hold high CEC concentration (Selassie et al. 2015; Sinore et al. 2018). Conservation measures caused a relatively higher CEC and cation exchange capacity in conserved soils than in non-conserved but the difference did not show statistical significance. Different researchers reported that the effect of SWC measures showed non-significant difference in the CEC content of the soil (such as Hailu et al. 2012; Hishe et al. 2017). On the other hand, the findings of Challa et al. (2016), Mengistu et al. (2016), and Selassie et al. (2015) reported significantly higher CEC contents in conserved soil.

The variation among research reports may be attributed to the level of effectiveness of SWC measures due to variations in conservation types, proper construction, and maintenance. Sinore et al. (2018) reported a significantly higher CEC and exchangeable bases in a soil treated with susbania and elephant grasses than in controlled soil. Supporting terracing with such plants/ grasses strengthens the bund, generate high biomass, and increases $\mathrm{OM}$ and better control of erosion, consequently increases $C E C$ in the soil.

\section{The effectiveness of soil and water conservation measures in different land uses}

The effect of conservation measures found to be different in grazing and cultivated land uses. This is indicated by a significant variation in SOC, SOM, TN, exchangeable $\mathrm{Na}^{+}$and $\mathrm{Mg}^{2+}$ in conserved and non-conserved cultivated land uses and only exchangeable $\mathrm{Na}^{+}$in grazing land uses. The highest sand fraction was recorded from non-conserved cultivated land and lowest in conserved grazing land. Similarly, Hishe et al. (2017) reported greater sand content in non-terraced farm land. The effect of conservation measures caused greater mean variation of clay content in grazing land uses than in cultivated land uses. The highest (31.3\%) and lowest (23.7\%) silt content was observed in non-conserved and conserved grazing land uses, respectively (Table 4). This result did not agree with the findings of Hishe et al. (2017) who reported that lowest silt content was recorded in non-terraced cultivated land uses.

A relatively lower bulk density, higher SOC, SOM, and total nitrogen were observed in conserved cultivated land than in grazing land uses as compared to their counterpart. Higher SOC concentration was observed in grazing land uses than in cultivated land uses. Abegaz et al. (2016) explained that higher concentration of SOC was observed in cultivated land which makes this land uses to loss SOM more quickly than grazing land uses. The effect of SWC measures has reduced the removal of soil particles, residues, and other organic matter. On the other hand, non-conserved soils are exposed to greater removal of these components that may lead to relatively better effectiveness of conservation measures in cultivated land uses.

The analysis result showed that the effectiveness of SWC was better and significant (for some soil fertility indicators) in cultivated land than in grazing land. This might be related with high removal of fine nutrient-rich soil particles due to soil erosion in cultivated land (Belayneh et al. 2019) and conservation structures reduced soil loss in conserved plots. The key informant interview indicated that little or no attention was given for maintenance of conservation structures mainly in grazing land. This is due to communal ownership of most of the grazing land uses and waiting for any community mass-mobilization. On the other hand, the destruction of conservation structures was very high due to year-round open grazing. The result was supported by Wolancho (2015), who stated that controlling SWC measures in communal grazing lands was poor and its effect was minimal.

\section{Some limitations of the SWC practices affecting its effectivness}

The effect of SWC showed important implications in reducing soil erosion, improving soil conditions, and thereby land rehabilitation. However, significant results were observed only in some soil fertility indicators. The construction, follow-up, and maintenance could be possible causes for limited effectiveness among others. In this regard, the key informant interview result indicated that the construction of physical structures has not been mostly following the recommended terrace dimensions. During data collection period, researchers also observed over flow of runoff, filled with sediments and damaged SWC structures.

The key informants indicated that so far, the construction of most of the physical structures has been constructed targeted reporting number of hectares covered by SWC works through community mobilization. The recommended and scientific standards have not been given due attention. This result was confirmed by Bekele et al. (2018) who stated that the spaces between successive graded bunds were somewhat wider than the recommended standards mainly due to lack of technical assistance in bund design and layout. Such conditions 
more likely increase erosion risk on the cropland due to the large amount of runoff accumulation in bund ditches (Molla and Sisheber 2017). Several problems were reported by Wolancho (2015) concerning the community mobilization campaign work such as poor foundations in stone bunds, poorly designed mounding, and compacting embankments in fanya juus and spacing between soil bunds. Little technical support makes SWC ineffective (Wolancho 2015).

The maintenance of SWC structures has been given little attention. The work of maintenance was entirely left for farmers after construction by community massmobilization and its maintenance depends on individual farmers' willingness. Some farmers maintain when damage occurred mainly in the sowing time. Our field observations also confirmed that conservation structures were filled with sediments without any maintenance and may not detain any more sediment and runoff. Most of the existing structures were demolished mainly related with high intensity of rainfall, sediment overload, and vulnerability to livestock damage (Molla and Sisheber 2017; Wolancho 2015). As a result, frequent removal of sediments and other maintenance is required (Wolancho 2015). This situation could probably limit the effectiveness of SWC structures for only some soil properties and did not result in significant variations in mean values for soil particle size distribution, bulk density, $\mathrm{pH}$, CEC, and available phosphorus in the Gumara watershed.

\section{The correlation between soil properties}

The correlation matrix implies that most of the soil physical and chemical properties vary together. Soil $\mathrm{pH}$ had a positive significant relationship with SOM, TN CEC, exchangeable $\mathrm{Na}^{+}, \mathrm{K}^{+}$, and $\mathrm{Ca}^{2+}$. This indicated that many of the soil properties vary together with soil $\mathrm{pH}$ and it determines the availability of other physicochemical properties of the soil and vice versa. The presence of high organic matter, CEC, and basic cations improved the $\mathrm{pH}$ of the soil (Sinore et al. 2018). Moderately significant negative relationships were also observed between bulk density and TN, clay content, and basic cations except $\mathrm{Ca}^{2+}$. This could be due to the availability of high organic matter and fine soil particles in the soil (Hishe et al. 2017); Sinore et al. 2018).

Principally, the availability of SOM, SOC, TN, CEC, and basic cations showed strong relationship. With respect to this, the implementation of SWC improved most of these soil properties significantly (such as SOC, SOM, TN, and some cations) in this study and other studies (Challa et al. 2016; Hishe et al. 2017; Sinore et al. 2018; Mengistu et al. 2016; Selassie et al. 2015). Therefore, it gives an important lesson that the improvement in SOM, CEC, and clay content can also indirectly influence other properties and rehabilitates the soil to be healthier through its aggregate effect.

\section{Conclusion}

SWC practices have been an important means to reverse the degraded land and limit further damages to the land resources. They have been a tool for the communities to care for their local environment. This study evaluated the effects of SWC practices in improving soil physicochemichal properties in Gumara watershed. In this regard, the study revealed that SWC resulted in improvement in soil nutrient content in Gumara watershed. Soil organic matter, soil organic carbon, total nitrogen, and exchangeable $\mathrm{Na}^{+}$and $\mathrm{Mg}^{2+}$ showed significantly higher mean values in conserved land as compared to non-conserved land. Furthermore, the mean values of soil $\mathrm{pH}$, bulk density, clay content, caution exchange capacity, and exchangeable $\mathrm{Ca}^{2+}$ were better following conserved plots than non-conserved plots, even if the difference was not statistically significant.

Our results also showed that the effectiveness of SWC measures was better in cultivated land than in grazing land. This could be mainly related with poor management and maintenance of conservation structures in grazing land, year-round open grazing with little attention for treatments. SWC practices are effective ways in minimizing soil erosion and improving soil fertility mainly in cultivated lands. However, in general, the issue of continuity (spatial and temporal), maintenance, and reconstruction of structures has been given little attention, which is among the main challenges for limited effect of SWC practices in the watershed.

As a result, regular community mobilization for conservation, assistance, maintenance, and reconstruction of demolished structures needs better attention from the concerned stakeholders, mainly the local government. Since conservation structures were constructed through community mass-mobilization in a campaign form, some individual farmers have been reluctant to retain and maintain structures for long. In addition, supporting SWC structures with grasses and trees is very important for strengthening their effectiveness in improving soil fertility and decrease soil erosion in the watershed.

\section{Abbreviations}

ANOVA: Analysis of variance; CSA: Central statistical authority; SPSS: Statistical Packages for Social Scientists; SWC: Soil and water conservation

\section{Acknowledgements}

The study was financed by Arba Minch University. Netsanet Belayneh, Aragaw Munuye and Amogn Alimaw are gratefully acknowledged for their great assistance in data collection. Authors would like to acknowledge Dega Damot District Authorities for allowing the study and some vehicle service. We would like to thank Natural Resources Management authorities of the district and Developmental Agents (watershed kebeles) for their cooperation 
in various forms during data collection. Finally, we acknowledge Debre Markos soil research and fertility improvement laboratory for lab analysis.

\section{Authors' detail}

Mengie Belayneh is an Assistant Professor and Lecturer in the Department of Geography and Environmental Studies, Mettu University, Mettu, Ethiopia. Mengie Belayneh attended his Bachelor and Master's Degree at Department of Geography and Environmental Studies in Wollo University and Mekelle University, Ethiopia respectively. Currently, he is a PhD student specialized in "Environment and Natural Resources Management" at Department of Geography and Environmental Studies, Arba Minch University, Arba Minch, Ethiopia. E-mail address: mengie1980@yahoo.com, Tel: + 251918662162, Box 318 Mettu University, Mettu, Ethiopia.

Teshome Yirgu (PhD) is an Associate Professor of Land Resources Management in Department of Geography and Environmental Studies, Arba Minch University, Arba Minch, Ethiopia. Email: teshome.yirgu@amu.edu.et, P.O. Box 21.

Dereje Tsegaye (PhD) is an Assistant Professor of Soil Science in Department of Plant Science, Arba Minch University, College of Agricultural Sciences, Arba Minch, Ethiopia. Email: dassdere@yahoo.com, P.O. Box 21.

\section{Funding}

The first author acknowledges Arba Minch University for financial support of this study.

\section{Availability of data and materials}

The datasets used and/or analyzed during the current study are available from the corresponding author on reasonable request.

\section{Authors' contributions}

MB has made significant contribution in conception and designing of the study, soil sample collection, analysis, and interpretation; TY and DT have contributed in designing the study, interpretation of results and editing, commenting and suggesting ideas in the manuscript preparation process. Finally, all authors read and approved the final manuscript for publication.

\section{Ethics approval and consent to participate}

Not applicable.

\section{Consent for publication}

All authors agreed and approved the manuscript for publication in ecological process

\section{Competing interests}

The authors declare that they have no competing interests.

\section{Publisher's Note}

Springer Nature remains neutral with regard to jurisdictional claims in published maps and institutional affiliations.

\section{Author details}

'Department of Geography and Environmental Studies, Mettu University, Box 318, Mettu, Ethiopia. ${ }^{2}$ Department of Geography and Environmental Studies, Arba Minch University, Box 21, Arba Minch, Ethiopia. ${ }^{3}$ Department of Plant Science, College of Agricultural Sciences, Arba Minch University, Box 21, Arba Minch, Ethiopia.

\section{Received: 30 April 2019 Accepted: 22 July 2019}

\section{Published online: 19 August 2019}

\section{References}

Abbate E, Bruni P, Sagri M (2015) Geology of Ethiopia: a review and geomorphological perspectives. In: Billi P (ed) Landscapes and landforms of Ethiopia. Springer, Dordrecht, pp 33-64. https://doi.org/10.1007/978-94-017-8026-1_2

Abegaz A, Winowiecki LA, Vagen T-G, Langan S, Smith JU (2016) Spatial and temporal dynamics of soil organic carbon in lands capes of the upper Blue Nile Basin of the Ethiopian highlands. Agric Ecosyst Environ 218:190-208. https://doi.org/10.1016/j.agee.2015.11.019

Adgo E, Teshome A, Mati B (2013) Impacts of long-term soil and water conservation on agricultural productivity: the case of Anjenie watershed, Ethiopia. Agric Water Manag 117:55-61. https://doi.org/10.1 016/j.agwat.2012.10.026

Adimassu Z, Mekonnen K, Yirga C, Kessler A (2014) Effect of soil bunds on run-off soil and nutrient losses, and crop yield in the central highlands of Ethiopia. Land Degrad Develop 25(6):554-564. https://doi.org/10.1002/ldr.2182

Amare T, Terefe A, Selassie YG, Yitaferu B, Wolfgramm B, Hurni H (2013) Soil properties and crop yields along the terraces and toposequece of Anjeni watershed, central highlands of Ethiopia. J Agric Sci 5(2):134-144. https://doi. org/10.5539/jas.v5n2p134

Bekele A, Aticho A, Kissi E (2018) Assessment of community based watershed management practices: emphasis on technical fitness of physical structures and its effect on soil properties in Lemo district, Southern Ethiopia. Environ Syst Res 7:20. https://doi.org/10.1186/s40068-018-0124-y

Belayneh M, Yirgu T, Tsegaye D (2019) Potential soil erosion estimation and area prioritization for better conservation planning in Gumara watershed using RUSLE and GIS techniques. Environ Syst Res 8:20. https://doi.org/10.1186/s4 0068-019-0149-x

Betrie GD, Mohamed YA, van Griensven A, Srinivasan R (2011) Sediment management modelling in the Blue Nile Basin using SWAT model. Hydrol Earth Syst Sci 15:807-818. https://doi.org/10.5194/hess-15-807-2011

Bewket W, Sterk G (2002) Farmers' participation in soil and water conservation activities in the Chemoga watershed, Blue Nile basin, Ethiopia. Land Degrad Develop 13:189-200. https://doi.org/10.1002/ldr.492

Black CA, Evans DD, White JL, Ensminger LE, Clark FE (1965) Methods of soil analysis. Part 1. Physical and mineralogical properties, including statistics of measurement and sampling. American Society of Agronomy, Madison

Blanca MJ, Alarcón R, Arnau J, Bono R, Bendayan R (2017) Non-normal data: Is ANOVA still a valid option? Psicothema 29(4):552-557. https://doi.org/10. 7334/psicothema2016.383

Central Statistical Agency of Ethiopia (CSA) (1994) Statistical abstract of Ethiopia. CSA, Addis Ababa

Central Statistical Agency of Ethiopia (CSA) (2007) Statistical abstract of Ethiopia. CSA, Addis Ababa

Challa A, Abdelkadir A, Mengistu T (2016) Effects of graded stone bunds on selected soil properties in the central highlands of Ethiopia. Int J Nat Resour Ecol Manage 1(2):42-50. https://doi.org/10.11648/j.jjnrem.20160102.15

Dagnew DC, Guzman CD, Zegeye AD, Tibebu TY, Getaneh M, Abate S, Zemale FA, Ayana EK, Tilahun SA, Steenhuis TS (2015) Impact of conservation practices on runoff and soil loss in the sub-humid Ethiopian highlands: the Debre Mawi watershed. J Hydrol Hydromech 63(3):210-219. https://doi.org/1 0.1515/johh-2015-0021

Degefu T, Woldemeskel E, Frostegard A (2011) Multilocus sequence analyses reveal several unnamed Mesorhizobium genospecies nodulating Acacia species and Sesbania sesban trees in southern regions of Ethiopia. Syst Appl Microbiol 34:216-226. https://doi.org/1 0.1016/j.syapm.2010.09.006

Environment for Development (2010) Green accounting puts price on Ethiopian soil erosion and deforestation. Retrieved from http://efdinitiative.org/ourwork/policy-interactions/green-accounting-puts-price-ethiopian-soil-erosionand-deforestation

Fikreyesus S, Kebebew Z, Nebiyu A, Zeleke N, Bogale S (2011) Allelopathic effects of Eucalyptus camaldulensis Dehnh. on germination and growth of tomato. Am-Eurasian J Agric Environ Sci 11(5):600-608

Gemechu A (2016) Estimation of soil loss using revised universal soil loss equation and determinants of soil loss in Tiro Afeta and Dedo districts of Jimma zone, Oromiya National Regional State, Ethiopia. Trends Agri Econ 9(1-3):1-12. https://doi.org/10.3923/tae.2016.1.12

Hailu W, Moges A, Yimer F (2012) The effects of 'Fanya juu' soil conservation structure on selected soil physical \& chemical properties: the case of Goromti watershed, Western Ethiopia. Resour Environ 2(4):132-140. https://doi.org/1 0.5923/j.re.20120204.02

Haregeweyn N, Berhe A, Tsunekawa A, Tsubo M, Meshesha DT (2012) Integrated watershed management as an effective approach to curb land degradation: a case study of Enabered watershed, northern Ethiopia. Environ Manag 50(6):1219-1233. https://doi.org/10.1007/s00267012-9952-0

Haregeweyn N, Tsunekawa A, Nyssen J, Poesen J, Tsubo M, Meshesha DT, Schutt B,

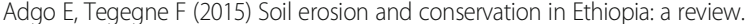
Prog Phys Geogr 39(6):750-774. https://doi.org/10.1177/0309133315598725

Haregeweyn N, Tsunekawa A, Poesen J, Tsubo M, Meshesha DT, Fenta AA, Nyssen J, Adgo E (2017) Comprehensive assessment of soil erosion risk for 
better land use planning in river basins: case study of Upper Blue Nile River Sci Total Environ 574:95-108. https://doi.org/10.1016/.jscitotenv.2016.09.019

Haregeweyn N, Tsunekawa A, Tsubo M, Meshesha D, Adgo E, Poesen J, Schutt B (2016) Analyzing the hydrologic effects of region-wide land and water development interventions: a case study of Upper Blue Nile basin. Reg Environ Chang 16(4):951-966. https://doi.org/10.1007/s10113-015-0813-2

Hishe S, Lyimo J, Bewket W (2017) Soil and water conservation effects on soil properties in the Middle Silluh Valley, northern Ethiopia. Int Soil Water Conserv Res 5:231-240. https://doi.org/10.1016/j.iswcr.2017.06.005

Hurni H (1993) Land degradation, famine and resources scenarios in Ethiopia. In: Pimental D (ed) World soil erosion and conservation. Cambridge University Press, Cambridge

Hurni H, Debele B, Zeleke G (2015) Saving Ethiopia's soils. In: Ehrensperger A, Ott C, Wiesmann U (eds) Eastern and southern Africa partnership Programme: highlights from 15 years of joint action for sustainable development. Centre for Development and Environment, University of Bern with Bern Open Publishing, Bern, pp 27-30. https://doi.org/10.7892/ boris.72023

Hurni H, Kebede T, Zeleke G (2005) Implications of changes in population, land use and land management for surface runoff in the upper basin area of Ethiopia. Mt Res Dev 25(2):147-154. https://doi.org/10.1659/0276-4741(2005 )025[0147:TIOCIP]2.0.CO;2

Husen D, Esimo F, Getechew F (2017) Effects of soil bund on soil physical and chemical properties in Arsi Negelle woreda, Central Ethiopia. Afr J Environ Sci Technol 11(10):509-516. https://doi.org/10.5897/AJEST2017.2275

International Monetary Fund (2005) Ethiopia: scaling up. Assessing the impact of a dramatic increase in aid in one of Africa's poorest countries. Finance Dev 42 Retrieved from https://www.imf.org/external/pubs/ft/ fandd/2005/09/andrews.htm

Jones JB (2001) Laboratory guide for conducting soil tests and plant analysis. CRC Press LLC, Boca Raton

Keno K, Suryabhagavan KV (2014) Multi-temporal remote sensing of landscape dynamics and pattern change in Dire district, Southern Ethiopia. J Geom 8(2): 189-194. https://doi.org/10.4172/2157-7617.1000226

Landon JR (2013) Booker tropical soil manual: a handbook for soil survey and agricultural land evaluation in the tropics and subtropics. Routledge, New York

Liu H (2015) Comparing Welch's ANOVA, a Kruskal-Wallis test and traditional ANOVA in case of heterogeneity of variance. Virginia Commonwealth University, Richmond Retrieved from https://scholarscompass.vcu.edu/etd/3985

Mekuria W, Veldkamp E, Haile M, Nyssen J, Muys B, Gebrehiwot K (2007) Effectiveness of exclosures to restore degraded soils as a result of overgrazing in Tigray, Ethiopia. J Arid Environ 69(2):270-284. https://doi.org/1 0.1016/j.jaridenv.2006.10.009

Mekuriaw A (2017) Assessing the effectiveness of land resource management practices on erosion and vegetative cover using GIS and remote sensing techniques in Melaka watershed, Ethiopia. Environ Syst Res 6:16. https://doi. org/10.1186/s40068-017-0093-6

Mekuriaw A, Heinimann A, Zeleke G, Hurni H (2018) Factors influencing the adoption of physical soil and water conservation practices in the Ethiopian highlands. Int Soil Water Conserv Res 6:23-30. https://doi.org/10.1016/j. iswcr.2017.12.006

Mengistu D, Bewket W, Lal R (2016) Conservation effects on soil quality and climate change. Land Degrad Develop 27:1603-1621. https://doi.org/10.1002//dr.2376

Ministry of Water Resources of Ethiopia (MoWR) (1998) Abbay river basin integrated development master plan, main report. Ministry of Water Resources, Addis Ababa

Molla T, Sisheber B (2017) Estimating soil erosion risk and evaluating erosion control measures for soil and water conservation planning at Koga watershed in the highlands of Ethiopia. Solid Earth 8:13-25. https://doi.org/1 0.5194/se-8-13-2017

Nyssen J, Clymans W, Descheemaeker K, Poesen J, Vandecasteele I, Vanmaercke M, Zenebe A, Van Camp M, Haile M, Haregeweyn N, Moeyersons J, Martens K, Gebreyohannes T, Deckers J, Walraevens K (2010) Impact of soil and water conservation measures on catchment hydrological response-a case in North Ethiopia. Hydrol Process 24(13):1880-1895. https://doi.org/10.1002/ hyp.7628

Nyssen J, Poesen J, Moeyersons J, Deckers J, Haile M, Lang A (2004) Human impact on the environment in the Ethiopian and Eritrean highlands - a state of the art. Earth Sci Rev 64(3):273-320. https://doi.org/10.1016/50012-8252(03)00078-3

Nyssen J, Poesen J, Moeyersons J, Haile M, Deckers J (2008) Dynamics of soil erosion rates and controlling factors in the Northern Ethiopian
Highlands—-towards a sediment budget. Earth Surf Process Landforms 33(5): 695-711. https://doi.org/10.1002/esp.1569

Osman KT (2013) Soils: principles, properties and management. Springer, Dordrecht. https://doi.org/10.1007/978-94-007-5663-2

Sakar D, Haldar A (2005) Physical and chemical method in soil analysis: fundamental concepts of analytical chemistry and instrumental techniques. New Age International (P) Ltd Publisher, New Delhi

Selassie YG, Anemut F, Addisu S (2015) The effects of land use types, management practices and slope classes on selected soil physico-chemical properties in Zikre watershed, North-Western Ethiopia. Environ Syst Res 4:3. https://doi.org/10.1186/s40068-015-0027-0

Sinore T, Kissi E, Aticho A (2018) The effects of biological soil conservation practices and community perception toward these practices in the Lemo District of Southern Ethiopia. Int Soil Water Conserv Res 6:123-130. https:// doi.org/10.1016/j.jswcr.2018.01.004

Stevens JP (2007) Intermediate statistics: a modern approach, 3rd edn. Lawrence Erlbaum Associates, New York

Temesgen M, Uhlenbrook S, Simane B, van der Zaag P, Mohamed Y, Wenninger J, Savenije HHG (2012) Impacts of conservation tillage on the hydrological and agronomic performance of Fanya juus in the upper Blue Nile (Abbay) river basin. Hydrol Earth Syst Sci 16:4725-4735. https://doi.org/10.5194/ hess-16-4725-2012

Van Reeuwijk LP (2002) Procedures for soil analysis, 6th edn. ISRIC, Wageningen Technical paper 9

Wolancho KW (2015) Evaluating watershed management activities of campaign work in southern nations, nationalities and peoples' regional state of Ethiopia. Environ Syst Res 4:6. https://doi.org/10.1186/s40068-015-0029-y

\section{Submit your manuscript to a SpringerOpen ${ }^{\circ}$ journal and benefit from:}

- Convenient online submission

- Rigorous peer review

- Open access: articles freely available online

- High visibility within the field

- Retaining the copyright to your article

Submit your next manuscript at $\boldsymbol{\nabla}$ springeropen.com 